\title{
WHAT IF ANIMALS CAN THINK?
}

\author{
MARY STERNBERG \\ Escondido, California
}

There are some ancient, moldy chestnuts that religions of the Judeo-Christian tradition will soon have to dump on the garbage heap. They deal with attitudes towards animals.

For hundreds of years, most religious leaders have adhered rigidly to the idea that animals lack consciousness and the ability to reason. This belief has made it easy for them to interpret tyrannically the passage in Genesis which proclaims that man is to have "dominion" over animals. This, in turn, has made it acceptable for religious people to overlook the hundreds of abuses and cruelties to which animals are constantly subjected.

This attitude can be sumarized as follows: if animals cannot think and must be dominated by us, we can do with them as we wish. We can hunt and trap them and wear their fur on oux backs; we can take them from their natural habitats, imprison them and force them to perform for our amisement; we can subject them to miserable lives in factory farms, then butcher and eat them; we can subject them to all manner of painful experiments for human profit; and so forth, and so forth. To date, none of the Judeo-Christian sects has officially condemned such abuses of "unthinking" animals.

In this attitude, Judeo-Christian religions have not progressed beyond the Sixteenth Century and Rene Descartes' belief that animals are machines whose behavior can be explained in purely mechanical terms. But, Descartes' theory has long been criticized for its inability to explain how the mind, which he considers immaterial, can interact with the body, which he considers material. Cartesian dualism was scientifically discredited in the Nineteenth Century by Darwin's demonstration that consciousness is an evolved characteristic and is, therefore, "reasonably viewed as being shared by members of many species in addition to Homo sapi-

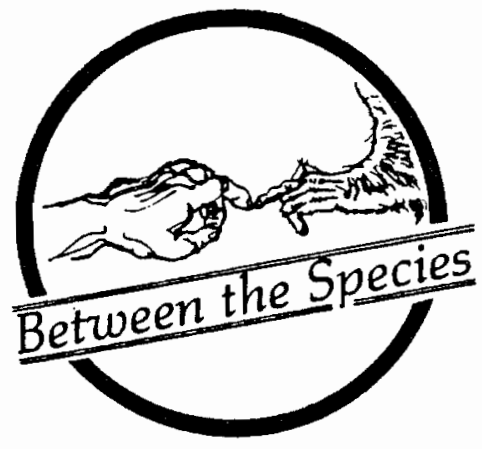

ens." [1]

In this century, Donald Griffin, an ethologist at Rockefeller University, who has been studying the cognitive processes of animals for many years, has reinforced Darwin's claim that consciousness is an evolved characteristic:

It evolved because it is efficient for an animal to organize its behavior in terms of mental images and mental goals.[2]

Reason is not an extra, luxuriant power any more than breathing is. Conscious thinking is simply what the brain does, whether it is the brain of a human or that of an animal.

Griffin supports his argument with scientific findings resulting from years of study of animals in their natural habitats. He has found that even the piping plover, a small seashore bird, makes the decision to do certain things, such as leading predators away from its nest. Apes have been found to be aware of themselves, to calculate others' intentions and even, like humans, to engage in deception. Griffin says that to disprove his findings, one would have

to assume that humans with nervous systems much like other mammals' have developed a totally unique ability. . . To argue that human brains are divorced from the animal kingdom is not only umparsimonious, it is conceited. [3]

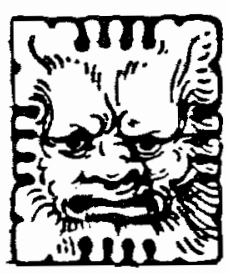

RELIGION 
On the philosophical side, Tom Regan, in his recent book The Case for Animal Rights has argued that animals merit respect because they are independent valuers. Regan points out that if we assume, as Descartes does, that human beings have a conscious mental life, then "it would be quite remarkable indeed if Homo sapiens were the only species whose members had this attitude."[4] To him, the crucial point is the survival value of consciousness. If consciousness were not of value in surviving in a changing environment, then conscious beings would not have survived in the first place. Thus, human survival shows the survival value of consciousness. Consequently, "we have every reason to suppose that the members of other [surviving] species are also conscious."[5] He agrees with Griffin that the better an animal un-

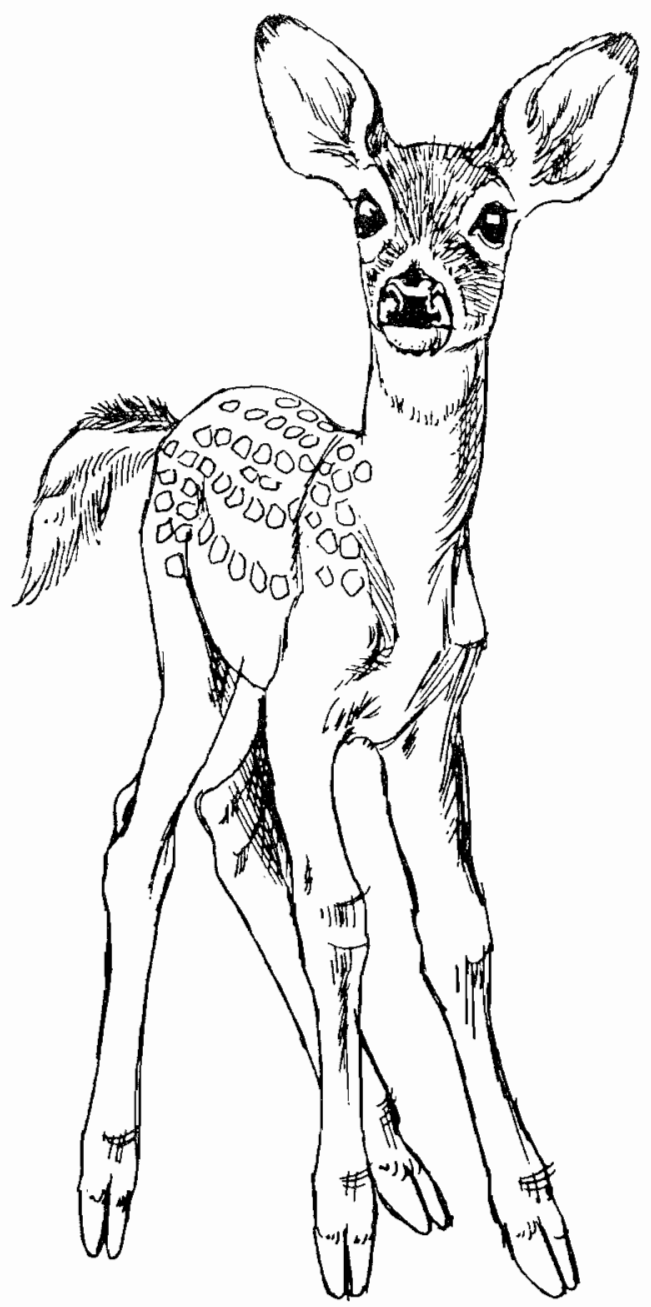

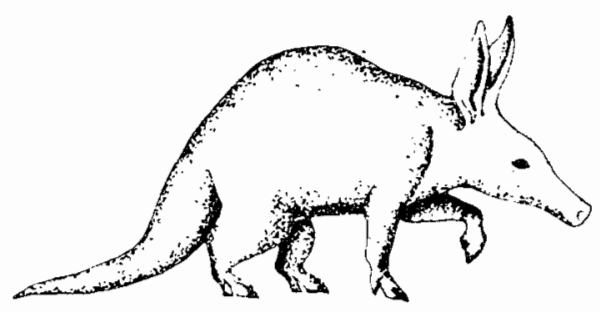

derstands its physical, biological, and social environment, the better it will adjust to actions that contribute to its evolutionary fitness. Regan's conclusion is that

Perception, memory, desire, belief, self-consciousness, intuition, a sense of the future are among the leading attributes of the mental life of normal manmalian animals aged one or more. [When we add emotion and the ability to feel pain to these,] we approach a fair rendering of the mental life of these animals. [6]

Considering these recent findings in science and philosophy, one wonders how much longer the religions can remain silent about animal abuse. Aren't they taking a terrible chance? Can they afford to be out of date in yet another area, especially one where being complacently out of date leads to so much suffering for thinking, feeling beings? Perhaps it is those who mindlessly continue the Judeo-Christian tradition concerning animals' irrational nature and man's ordained dominance who are Descartes' unthinking machines.

\section{Notes}

1. Torn Regan, The Case for Animal Rights (Berkeley: University of California Press, 1983), p. 32.

2. Alison Jolly, "A New Science that Sees Animals as Conscious Beings," Smithsonian (March, 1985), p. 67.

3. Ibid.

4. Regan, op. cit., p. 18 .

5. Ibid., p. 19.

6. Ibid., p. 81 . 